\title{
Cross-country differences in graduate overeducation and its persistence
}

Citation for published version (APA):

Verhaest, D., \& van der Velden, R. K. W. (2010). Cross-country differences in graduate overeducation and its persistence. Researchcentrum voor Onderwijs en Arbeidsmarkt, Faculteit der Economische

Wetenschappen. ROA Research Memoranda No. 7 https://doi.org/10.26481/umaror.2010007

Document status and date:

Published: 01/01/2010

DOI:

10.26481/umaror.2010007

Document Version:

Publisher's PDF, also known as Version of record

\section{Please check the document version of this publication:}

- A submitted manuscript is the version of the article upon submission and before peer-review. There can be important differences between the submitted version and the official published version of record.

People interested in the research are advised to contact the author for the final version of the publication, or visit the DOI to the publisher's website.

- The final author version and the galley proof are versions of the publication after peer review.

- The final published version features the final layout of the paper including the volume, issue and page numbers.

Link to publication

\footnotetext{
General rights rights.

- You may freely distribute the URL identifying the publication in the public portal. please follow below link for the End User Agreement:

www.umlib.nl/taverne-license

Take down policy

If you believe that this document breaches copyright please contact us at:

repository@maastrichtuniversity.nl

providing details and we will investigate your claim.
}

Copyright and moral rights for the publications made accessible in the public portal are retained by the authors and/or other copyright owners and it is a condition of accessing publications that users recognise and abide by the legal requirements associated with these

- Users may download and print one copy of any publication from the public portal for the purpose of private study or research.

- You may not further distribute the material or use it for any profit-making activity or commercial gain

If the publication is distributed under the terms of Article $25 \mathrm{fa}$ of the Dutch Copyright Act, indicated by the "Taverne" license above, 
Maastricht University

Research Centre for Education and the Labour Market | ROA

\section{Cross-country differences in graduate overeducation and its persistence}

Dieter Verhaest

Rolf van der Velden

\section{ROA Research Memorandum}

ROA-RM-2010/7

Research Centre for Education and the Labour Market Maastricht University

P.O. Box 616,6200 MD Maastricht, The Netherlands

$\mathrm{T}+31433883647 \mathrm{~F}+31433884914$

secretary-roa-sbe@maastrichtuniversity.n www.roa.nl 


\title{
Cross-country differences in graduate overeducation and its persistence
}

\author{
Dieter Verhaest \\ Rolf van der Velden
}

ROA-RM-2010/7*

April 2010

Research Centre for Education and the Labour Market

Maastricht University

P.O. Box 616, 6200 MD Maastricht, The Netherlands

$\mathrm{T}+31433883647 \mathrm{~F}+31433884914$

secretary-roa-sbe@maastrichtuniversity.nl

www.roa.nl

\footnotetext{
* The ROA Research Memorandum Series was created in order to make research results available for discussion, before those results are submitted for publication in journals.
} 


\section{Abstract}

\section{Cross-country differences in graduate overeducation and its persistence ${ }^{* *}$}

We investigate the factors that contribute to the cross-country variation in graduate overeducation and its persistence by means of multi-level analysis. Our analysis is based on data from representative surveys among graduates in thirteen European countries and Japan and focuses on the jobs six months and five years after graduation. Major factors to explain the cross-country variation in overeducation and its persistence are found to be differences in the structural imbalance between the overall demand and supply of skilled workers, differences in the imbalance between the demanded and supplied fields of study and differences in the business cycle at the time of graduation. Also the quality and orientation (general versus vocational) of the educational program are important, but particularly to explain within-country differences. Finally, labour market institutions such as the strictness of the employment protection legislation are found to be less important.

Dieter Verhaest

Hogeschool-Universiteit Brussel

Stormstraat 2

B-1000 Brussels

Belgium

dieter.verhaest.hubrussel.be
Rolf van der Velden

ROA

Maastricht University

P.O. Box 616

6200 MD Maastricht

The Netherlands

r.vandervelden@maastrichtuniversity.nl

** We would like to thank Arnaud Dupuy, Andries de Grip, Freddy Heylen, Ben Kriechel, Joan Muysken, and the participants of the sixteenth workshop of the European Research Network on Transitions in Youth (Bamberg, 1013/09/08) for their helpful comments and suggestions. 


\section{Introduction}

In most developed countries, investments in education have gradually increased over the past decades. This evolution has resulted in growing concerns among researchers and policy-makers about so-called overeducation in the labour market. A large number of studies indeed found that a substantial part of the working population in most developed countries works in jobs with requirements below their level of education (Groot and Maassen van den Brink, 2000; McGuinness, 2006). Moreover, it is usually found that the return to education is lower for these workers than for those working in jobs with requirements that match their education (Hartog, 2000). Similarly, several studies noted that overeducation can have strong negative effects on the mental well-being of the workers (Allen and van der Velden, 2001; Verhaest and Omey, 2009). Yet, despite this vast literature, several questions remain to be answered.

A first question is related to the differences in the level of overeducation across countries. Studies for the US labour market usually note somewhat higher incidences of overeducation than studies for European countries such as The Netherlands (Groot and Maassen van den Brink, 2000; McGuinness, 2006). Yet, results are difficult to compare because of the different techniques applied for the measurement of overeducation and the different samples and time periods under focus. Consequently, few attempts have been made to detect the driving factors behind overeducation at the country level ${ }^{1}$. A scarce exception is a study by Di Pietro (2002), who focussed on differences within the European Union on the basis of comparative labour force data for 1995. He noted relatively high levels of overeducation among the highly educated in the Southern European countries and the UK compared to other member countries like

Germany, France or The Netherlands. Further analyses revealed a positive impact on these levels of the change in the percentage of educational attainment of the population and the strictness of employment protection legislation, and a negative effect of the change in $R \& D$ investments. Overeducation was otherwise found to be unrelated to the unemployment rate. This conclusion with respect to the unemployment rate was also made by Groot and Maassen van den Brink (2000) on the basis of a meta-analysis of the literature. They found a positive relation between overeducation and the labour force growth rate. So, the results of both studies suggest that cross-country differences in overeducation rather result from structural differences in demand and supply than from cyclical fluctuations. However, several issues stay unclear. That the incidence of overeducation is related to the growth in the supply of educated workers, for example, does not necessarily imply that countries with a more highly educated work force also face substantially more overeducation problems. After all, supply might create its own demand with some lags. Moreover, although the business cycle seems not to be a decisive factor in the explanation of the overall level of overeducation, it might still account for cross-country differences in overeducation among particular groups such as new labour market entrants. Additionally, given the strong differences in structural unemployment across various countries, the unemployment rate might not be a suitable indicator to account for cyclical differences across countries. Finally, also other factors such as the institutions with respect to the educational system might play a role. 
A second question is related to the persistence of overeducation for individual workers. According to the career mobility theory by Sicherman and Galor (1990), overeducation is not problematic as it is the result of a career mobility plan. Yet, the extent to which overeducation is a temporary problem for individuals seems to differ across countries. Several studies for the US (Sicherman, 1991; Robst, 1995a; Rubb, 2003) and for the Netherlands (Dekker et al., 2002; Groot and Maassen van den Brink, 2003; Groeneveld and Hartog, 2004) concluded that overeducation is rather a temporary problem for most workers. Rubb, for example, estimated a yearly exit rate out of overeducation of about 20\%. However, for British, German, or Belgian workers, overeducation seems to be much more permanent (Battu et al., 1999; Büchel and Mertens, 2004; Dolton and Vignoles, 2000; Sloane et al., 1999; Verhaest and Schatteman, 2010). The example of Germany suggests that a relatively low overall level of overeducation not necessarily implies that overeducation is rather a temporary problem for those affected by it. So, also with respect to the persistence of overeducation, additional research is needed to understand what drives the differences across countries. The only study that focussed more profoundly on these country differences is a study by Scherer (2004), who made a comparison of the British, German and Italian labour market. Although her results indicated that overeducation is rather a persistent problem in all three countries, she also found that the negative consequences of overeducation for the future career are less pronounced in the UK compared to Italy and Germany. Along with the results for the US on the persistence of overeducation in other studies, this suggests that labour market flexibility can also reduce the degree to which overeducation is a persistent problem for individuals. However, whether this observed relation should be attributed to other underlying factors such as cyclical fluctuations, the educational institutions, or the overall supply of educated workers remains to be investigated.

The central aim of this paper is to investigate some of the factors underlying cross-country differences in overeducation and its persistence in more detail. To do so, we make use of the REFLEX-data on the transition from tertiary education to work in fifteen European countries and Japan. These data enable to measure overeducation in a consistent way across countries for graduates that entered the labour market in the year 2000. Moreover, a comparison between the first employment after leaving school and the employment five years later enables to investigate the extent to which overeducation is a persistent problem. By means of multi-level techniques, we investigate which factors contribute to the cross-country variation in the incidence of overeducation in the first job, the job five years later and the overall exit rates out of overeducation and good matches between these two moments in time.

We conclude that a substantial part of the cross-country variation in overeducation can be attributed to differences in the imbalance between the demanded and supplied fields of study on the labour market. This holds primarily for the overeducation during the transition phase (i.e. in the first job). The two other factors that are important in explaining cross-country differences in overeducation are the business cycle and the relative supply of educated workers. Graduates that enter the labour market during a recession and/or face fierce competition from other highly educated individuals are much more likely to be overeducated in their first job. Interestingly, we find no relation between overeducation and its 
persistence and the absolute share of highly educated individuals in a country. This seems to confirm the hypothesis that supply might create its own demand. Finally, conversely to the previous study by Di Pietro (2002), we found no evidence of a positive relation between the incidence of overeducation and the strictness of the employment protection legislation.

Also the quality and orientation of the study program are important, primarily for the explanation of within-country differences in overeducation. This seems to support the heterogeneous skills hypothesis which states that those who are formally overeducated just lack the necessarily skills (see, e.g., Allen and van der Velden, 2001). The results with respect to the orientation of the study program are more nuanced. Those with a generally oriented program have a lower likelihood to have a good match in the first job and to stay in a good match. Their ability to use overeducation as a stepping stone, however, was found to be higher. These findings are consistent with the view that vocational systems are successful in the acquisition of specific skills, whereas general systems particularly result in the acquisition of generic skills.

The structure of this paper is as follows. In Section 2 we elaborate the theoretical framework and formulate the hypotheses. Section 3 describes the data. In Section 4 we elaborate the estimation methodology. Section 5 contains the results followed by Section 6 with the conclusions.

\section{Theoretical framework and hypotheses}

The Demand and Supply context

Business cycle dynamics deliver a potential explanation for cross-country differences in graduate overeducation. Several theories predict that overeducation, measured at the same point in time, will be higher in countries that face a recession. Wage rigidity models put forward that labour market adjustments to temporary shocks occur by a change in the assignment of workers to occupations rather than by wage changes (see, e.g., Reder, 1955; Hall, 1974; Thurow, 1975; Okun 1981). For new matches, employers change selection and hiring criteria; in existing matches, workers are assigned to other tasks or fired. Besides, job search models predict that longer expected search durations urge job seekers to temporarily accept a simple job and to pursue their search on-the-job (Gautier, 2002; Dolado et al., 2009). As already stated, little empirical evidence thus far confirmed that cyclical fluctuations are indeed important to explain overeducation at the macro level. Moreover, also micro-economic studies often find no or only partial evidence for the hypothesis that regional differences in the unemployment rate influence the probability to be overeducated (see, e.g., Büchel and van Ham, 2003; Verhaest and Omey, 2010; Verhaest and Schatteman, 2010). Yet, the unemployment rate only measures the business cycle in an indirect way. Overeducation might even moderate the relation between unemployment and the business cycle if job seekers indeed prefer employment in simple jobs over staying unemployed. Besides, countries and regions face large differences in their structural unemployment. Finally, none of the macro-economic stu-

dies focussed on differences in overeducation among young graduates. As the acquisition of firm- and 
occupation-specific human capital makes it less efficient to fire or reassign more experienced workers, we might expect that the relation between the business cycle and overeducation is more pronounced for new labour market entrants or new hires such as school leavers. That this is not unlikely is demonstrated by two empirical findings in the literature. Firstly, Devereux (2000) found that demand shocks particularly induce a change in the tasks of low-tenure workers within firms. In a later paper (Devereux, 2002), he also showed that the quality of new hires in terms of educational qualifications rises during recessions. Secondly, also youth unemployment is generally found to be much more sensitive to the business cycle than adult unemployment (OECD, 2008a). So, we test the following hypotheses:

(H1) Part of the between-country variation in overeducation can be attributed to cyclical factors

(H2) Cyclical fluctuations are more important for the explanation of overeducation at the start of the career than later on.

Countries might also differ in the extent to which there is a more structural imbalance between the demand and supply of educated workers. Although most developed countries have gradually increased their investments in education, there are still substantial differences in the overall share of higher educated individuals (see Barro and Lee, 2001). Since the early seventies, it has regularly been stated that these huge investments in education inevitably result in more overeducation (see, e.g., Berg, 1970; Livingstone, 1998). Yet, several economists have theoretically shown that the supply of skilled workers might create its own demand. Snower (1995), for instance, demonstrated that high investments in education are a prerequisite for the creation of high productivity jobs. Acemoglu (1998) then again showed that an oversupply of highly skilled workers is likely to induce skill-biased technological change. This suggests that the countries with a high share of skilled workers are not necessarily those who face a greater imbalance between the demand and supply of skilled workers. So, we test whether:

(H3) Part of the between-country variation in overeducation can be attributed to differences in the structural imbalance between the demand and supply of skilled workers

(H4) The incidence of overeducation is unrelated to the absolute share of skilled workers in the working population

Finally, also the composition of this supply in terms of field of study probably plays a role. Some fields are more demanded on the labour market than others. Hence, micro-economic studies regularly show that the field of study has a substantial impact on the probability to be overeducated (McGuinness, 2003; Frenette, 2004). So, we can expect that overeducation is also more prevalent in those countries with a more marked imbalance between the fields of study demanded by employers and those supplied by labour market entrants. Since workers can compensate their lack of field-specific skills by additional training, we expect that this explanation is particularly relevant at the start of the labour market career but less later on.

(H5) Part of the between-country variation in overeducation can be attributed to differences in the imbalance between demanded and supplied fields of study on the labour market.

(H6) Imbalances between the demanded and supplied fields of study are more important for the explanation of overeducation at the start of the labour market career than later on 
Along with the importance of imbalances in demand and supply, also the role of the institutional context will be investigated. Firstly, the overall quality and selectivity of the educational system in a country is likely to be important. Consider a country where the government decides to save on the budget for tertiary education, for instance through a reduction of the number of professors per student or through the implementation of more selective admission criteria. If this results in a drop of the average productivity of graduates, employers will apply more stringent selection criteria for these types of job seekers (Green et al., 2002). So, we expect that the overall quality and selectivity of the educational system has a negative impact on the overall incidence of so-called nominal overeducation and its persistence. Several withincountry studies have already established that the quality or prestige of the study program or institutions is a factor to explain overeducation at the individual level (see, e.g., Robst, 1995b; McGuinness, 2003; Di Pietro and Cutillo, 2006). Moreover, to the extent that employers have more reliable information regarding the average productivity of graduates than about their individual productivity, we might expect that this effect is even more pronounced at more aggregate levels. Hence, the following hypotheses will be tested regarding the quality and selectivity of the study program:

(H7) Part of the between-country variation in graduate overeducation can be attributed to differences in the quality and selectivity of the educational system

(H8) The overall quality and selectivity of the study program has a positive impact on the probability of a good match in the first job, on the transition from overeducation to a good match as well as on the likelihood to stay in a good match

Secondly, also whether the system is rather generally or vocationally oriented might play a role. Vocational systems particularly focus on the acquisition of specific skills that are needed for a particular occupation. General systems, on the other hand, focus more on the acquisition of generic skills which enable to learn the necessarily specific skills more quickly on-the-job. So, we can expect that countries with a vocational educational system face a lower incidence of overeducation in the first job, whereas countries with a more general system might be better in avoiding overeducation persistence. In a Belgian study among secondary education school leavers (Verhaest and Schatteman, 2010), it was indeed found that those who attended a general oriented program have a higher probability to experience a career with a first temporary period of overeducation. Also with respect to the orientation of the study program, aggregate effects might be even more pronounced if employers have only imperfect information regarding the content of the individual program.

(H9) Part of the between-country variation in overeducation can be attributed to differences in the vocational orientation of the educational system

(H10) Vocationally oriented programs are particularly successful in enhancing the probability on a good match in the first job, but less in enhancing the transition from overeducation to a good match 
Finally, also labour market institutions might play a role. Employment protection laws, for instance, reduce the overall employment opportunities of outsiders such as school leavers. Moreover, employers might rely more on internal promotions for their new vacancies. So, we expect that countries with stringent employment legislation face a higher incidence of overeducation at labour market entry. With respect to the degree of overeducation persistence, predictions are less clear. Whereas internal promotions enhance the probability to make the transition from overeducation to a good match, they make it more difficult to obtain a higher level job with a different employer. Finally, the probability to keep a good match is likely to be higher if individuals are protected against dismissal.

(H11) Part of the between-country variation in overeducation can be attributed to differences in labour market protection legislation

(H12) The degree of labour market protection has a negative impact on the probability on a good match in the first job, and a positive impact on the probability to stay in a good match

\section{Data and descriptive analyses}

The analysis is based on data of the REFLEX survey, which was carried out among graduates in the following 16 countries: Austria, Belgium-Flanders, Czech Republic, Estonia, Finland, France, Germany, Italy, Japan, the Netherlands, Norway, Portugal, Spain, Sweden, Switzerland and the UK. For each country, a representative sample of graduates from tertiary education who got their degree in the academic year 1999/2000 has been approached at the end of 2005. The data include, amongst others, detailed information on the study program, the first employment after graduation and the employment at the time of the

survey. For detailed information on the project, we refer to Allen and van der Velden (2007). Two countries, namely Estonia and Sweden, are excluded from our analysis. As a non-OECD country, not all aggregate indicators that are used in this study are available for Estonia. Sweden is excluded since its survey design largely deviates from that of the other countries that were involved in the project. For the remaining countries, we restrict the sample to those who were never enrolled in any other tertiary education program than the one they finished in 1999/2000. Moreover, with respect to the first job, we focus on those who were already employed six months after graduation. Finally, to avoid overrepresentation of certain countries, the sample of the multivariate analyses is restricted to no more than 2.000 randomly chosen cases per country. A further drop of observations with missing values delivers a final sample of 9505 graduates for the job immediately after graduation and 11184 individuals for the employment at the time of the survey ${ }^{2}$. The descriptive country results, reported in this section, are based on weighted data.

In Table 1, we report the incidence of overeducation by country for both job observations. The average incidence of overeducation in the first job is $26 \%$. Yet, we find substantial differences across countries. Countries like Italy, the UK and particularly Spain face a substantial overeducation problem among young graduates in their first job. At the other spectrum, we find countries like France, Germany, Portugal and Switzerland with overeducation incidences of less than 20\%. For every country, we observe a 
decline in the overeducation problem during the first five years after graduation. On average, the incidence of overeducation is about 10 pp lower in the current job compared to the first job. It is not surprising to note that the largest drop is realized by those countries with a high initial incidence of overeducation. In the UK, for example, the incidence of overeducation dropped by a half between the two observation points. A notable exception, however, is Japan where the drop amounts to a little 5 pp, despite the relatively high initial incidence of overeducation. Conversely, the drop is in general much less pronounced in the countries with a low initial overeducation problem. The most remarkable example is Germany, where the decline is hardly more than $1 \mathrm{pp}$. Hence, some countries with rather moderate initial levels of overeducation such as The Netherlands and the Czech Republic catch up with Germany five years after graduation.

Table 1: The incidence of overeducation six months and five years after graduation

\begin{tabular}{lccc}
\hline & 6 months after graduation & 5 years after graduation & Change over time \\
\hline Spain & 0,450 & 0,267 & $-0,183$ \\
United Kingdom & 0,410 & 0,204 & $-0,206$ \\
Italy & 0,380 & 0,193 & $-0,187$ \\
Japan & 0,298 & 0,251 & $-0,047$ \\
Belgium & 0,273 & 0,156 & $-0,117$ \\
The Netherlands & 0,271 & 0,121 & $-0,150$ \\
Czech Republic & 0,245 & 0,116 & $-0,129$ \\
Austria & 0,238 & 0,136 & $-0,102$ \\
Norway & 0,229 & 0,153 & $-0,076$ \\
Finland & 0,213 & 0,113 & $-0,100$ \\
France & 0,181 & 0,114 & $-0,067$ \\
Switzerland & 0,167 & 0,125 & $-0,042$ \\
Germany & 0,151 & 0,138 & $-0,013$ \\
Portugal & 0,136 & 0,100 & $-0,036$ \\
Country average & 0,260 & 0,156 & $-0,104$ \\
\hline Data source: REFLEX & & &
\end{tabular}

Data source: REFLEX, own calculations.

Aggregate figures discern the individual transitions made by the graduates. Some individuals will find an appropriate job after having been overeducated in the first job; others who immediately find an appropriate job might fall back into overeducation thereafter; still others will keep the same match status during their early career. So, to get a clearer picture of the country differences in overeducation persistence, we also report the country incidences of overeducation in the last job conditional on the status in the job 6 months after graduation. As shown in Table 2, the countries that face the highest persistence are Germany, Switzerland and particularly Japan: about two thirds of the Japanese graduates who were overedu- 
cated in their first job remain overeducated five years later. For Czech, French and Dutch graduates conversely, overeducation is much more a temporary problem. Of course, having a good chance to find a job with a good match does not exclude that individuals fall back into overeducation later on. So, we also report the incidence of overeducation conditional on being in a good match in the first job. In every country, this conditional probability is lower than $10 \%$. Nevertheless, also with respect to this indicator, some remarkable differences across countries show up. Japan, for example, combines a high overeducation persistence with a relatively low stability of good match positions. Italy, by contrast, is characterized by an overall low stability of match positions: this country combines a below average overeducation persistence with a relatively high probability to fall back in overeducation after an initial good match. Finland, the Czech Republic and France have the lowest instability of good matches, which are also countries with relatively low levels of overeducation persistence.

Table 2: The incidence of overeducation 5 years after graduation conditional on the overeducation status 6 months after graduation

\begin{tabular}{lcc}
\hline Status 6 months after graduation & Good match & Overeducated \\
\hline Spain & 0,065 & 0,487 \\
United Kingdom & 0,051 & 0,419 \\
Italy & 0,096 & 0,380 \\
Japan & 0,086 & 0,664 \\
Belgium & 0,056 & 0,358 \\
The Netherlands & 0,047 & 0,302 \\
Czech Republic & 0,029 & 0,326 \\
Austria & 0,056 & 0,385 \\
Norway & 0,043 & 0,487 \\
Finland & 0,026 & 0,391 \\
France & 0,032 & 0,329 \\
Switzerland & 0,041 & 0,580 \\
Germany & 0,051 & 0,538 \\
Portugal & 0,047 & 0,410 \\
Country average & 0,052 & 0,433 \\
\hline
\end{tabular}

Data source: REFLEX, own calculations.

In general, the observed differences in the level of overeducation are in line with the results of Di Pietro (2002), who noted relatively high levels of overeducation in the UK, Spain and Italy, and relatively low levels in France, Germany and The Netherlands. Also some of our results on the persistence of over-eduaion are in line with previous findings in the literature. The strong persistence in Germany, for example, is largely confirmed by previous research. Similarly, several other studies for The Netherlands already found that overeducation is rather a temporary problem in this country. Finally, the rather moderate 
persistence in the UK in comparison to Germany is in line with Scherer's (2004) conclusions. We do not find, however, that overeducation is rather persistent in Italy or Belgium. Of course, the degree of persistence might change over time due to cyclical developments or a change in institutional context. Moreover, we also focus on a specific sample of graduates, which might differ in the characteristics of their study program from the individuals that were involved in other studies. Which of these factors are important will be investigated in the remainder of the paper.

\section{Estimation methodology and model specifications}

Four dependent variables are analysed in this paper: the probability of a good match in the first job, the probability of a good match in the current job, the probability of a transition from overeducation in the first job to a good match in the current job, and the probability to stay in a good match. To analyse the determinants of these four indicators, we estimate a series of multi-level probit models. Multi-level or random coefficient models allow to control both for variables that are measured at the individual level and variables that are related to more aggregate levels such as the country. Van der Velden and Wolbers (2003), for example, applied such techniques to investigate cross-country differences in the employment opportunities of young people. Compared to an analysis on the basis of aggregate data, this approach delivers a number of advantages in our case. Firstly, effects resulting from differences across countries in the composition of the cohorts - for instance with respect to gender or age - can easily be accounted for. Secondly, it allows to compare the aggregate effects of variables such as the quality and orientation of the educational program with their individual-level effect. As already stated, these effects should not necessarily be the same. Hence, a simultaneous estimation of both types of effects is likely to deliver a more comprehensive picture regarding the role of these characteristics of the educational institutions.

Finally, as will be explained below, differences in the imbalances between the demanded and supplied fields of study (cf. Hypotheses 5 and 6) can easily be accounted for through the inclusion of field of study random effects. For a more detailed overview on multi-level modelling, we refer to Snijders and Bosker (1999).

In this paper, we consider a three-level structure whereby individuals $i$ are nested in fields of study $s$, which in turn are nested in countries $c$. Several models are estimated, with the following general form:

$y_{i s c}=\boldsymbol{\beta}_{1} \mathbf{X}_{\mathrm{isc}}+\boldsymbol{\beta}_{2} \mathbf{S}_{\mathrm{sc}}+\boldsymbol{\beta}_{3} \mathbf{C}_{\mathrm{c}}+R_{i s c}+U_{s c}+V_{c}$

Whereby $y$ is a latent variable, $\mathbf{X}$ is a vector of characteristics of individual $i, \mathbf{S}$ is a vector of characteristics of the field of study $s, \mathbf{C}$ is a vector of characteristics of country $c$ and $R, U$ and $V$ are random error terms. The number of random effects is 14 at the country level and 110 at the study field level ${ }^{3}$. These models are estimated by means of the GLLAMM command that was implemented in Stata by Rabe-Hesketh and Skrondal (2008) ${ }^{4}$. To assess how much of the overall variance in these models can be 
attributed to unexplained country-level effects, we make use of the extended version of the McKelvey and Zavoina (1975) R² measure for discrete choice models (see Snijders and Bosker, 1999). ${ }^{5}$

Our baseline model, Model 1a, only contains an intercept and additional random effects at the country level. In Model 1b, we include the covariates that are measured at the individual level $(\mathbf{X})$. In that way, we are able to assess how much of the overall variation of the four dependent variables in our sample can be ascribed to country-level differences after control for compositional effects. The included covariates are, amongst others, a dummy for gender, the age of the graduate, a dummy for whether the degree of the graduate provides access to a $\mathrm{PhD}$, and the grades. This last variable is based on the respondents' assessment of their grade in the year of graduation relative to other students. In most countries, individuals were asked: 'How do you rate this grade compared to the students that graduated from your study program?'. In the Japanese version, however, only a question regarding the absolute grade is posed. To create a uniform variable, both the answers on the absolute grade for Japan and the answers on the relative grade for the other countries are standardized for each country ${ }^{6}$.

In Model 2a, we also include random effects at the level of the study fields. The country-level random effects in this model thus represent the average performance of fields of study within a country. This specification takes into account that the extent to which graduates choose for more or less successful study fields can differ across countries. So, the change in the unexplained variance at the country level after the inclusion of the random effects for field of study gives an indication of the extent to which between-country differences can be attributed to differences in the imbalance between the demanded and supplied fields of study on the labour market (cf. Hypothesis 5 and 6). Model $2 \mathrm{~b}$ further controls for two variables that are measured at the study field level (S), namely the average quality and the average orientation (general versus vocational) of the study program within each study field (cf. Hypotheses 7, 8, 9, and 10). These two variables are derived from the respondents' assessments of six aspects of the content of their study program, which had to be rated on a scale from 1 (not at all) to 5 (to a very high extent). A principal component analysis was executed on the answers, with the loadings of the first two factors being reported in Table 3. The first factor scores high on the extent to which the programme was regarded to be demanding, the extent to which employers are familiar with it as well as the extent to which it was academically prestigious. Hence, this factor is used as a proxy for the overall quality of the study program. The second factor clearly represents the extent to which the program is generally oriented. Average scores within each field of study give an indication of their quality and orientation. The individual deviations from these averages are additionally included as individual-level covariates in all specifications except in the baseline model.

In a final series of models (Model 3a to 3e), we also include the variables that are measured at the country level (C). In Model 2b, it is assumed that the country-level effects of the characteristics of the study program are equal to their study field-level effects. In a first specification, we relax this assumption and further decompose the averages at the field of study level into averages at the country level and their 
deviations from these country level averages. Further, we include the Output Gap - i.e. the relative difference between actual and potential GDP - in the year 2000, computed by the OECD (2006), to account for the business cycle (cf. Hypotheses 1). For the probability on a good match in the last job, we also estimate an alternative specification with the output gap in 2005 as indicator (cf. Hypothesis 2). The output gap measures the overall tension in the economy, whereby a positive value indicates excess demand. Given the cross-country differences in structural unemployment, it is a more suitable indicator to account for cyclical differences than the unemployment rate. Moreover, it is a more direct measure of the business cycle compared to the unemployment gap - i.e. the deviation of the unemployment rate from its natural rate. As robustness checks, we execute some estimations on the probability on a good match in the last job with these two last indicators as alternative predictors ${ }^{7}$. The indicators for the supply and demand of skilled workers (cf. Hypothesis 3 and 4) are respectively the share of highly educated individuals in the population aged 25 or older (Barro and Lee, 2000) and the gross domestic expenditure on R\&D (OECD, 2008b), both for the year $2000^{8}$. The relative oversupply is then measured as the difference between the standardized values of these two indicators. Finally, Hypotheses 11 and 12 are tested by the inclusion of a composite measure, developed by the OECD (2004), on the overall strictness of the employment protection legislation.

Table 3: Derivation of the quality and the orientation of the study program: Principal Components rotated factor loadings

\begin{tabular}{lcc}
\hline $\begin{array}{l}\text { To what extent did the following descriptions apply to } \\
\text { your study programme? }\end{array}$ & $\begin{array}{c}\text { Component } 1 \\
\text { (Quality of the } \\
\text { programme) }\end{array}$ & $\begin{array}{c}\text { Component } 2 \\
\text { (General orientation } \\
\text { of the programme) }\end{array}$ \\
\hline Programme was generally regarded as demanding & 0.400 & 0.094 \\
Employers are familiar with the content of the programme & 0.386 & -0.132 \\
There was freedom in composing your own programme & -0.103 & 0.590 \\
Programme had a broad focus & 0.077 & 0.518 \\
Programme was vocationally oriented & 0.299 & -0.234 \\
Programme was academically prestigious & 0.374 & 0.262 \\
\hline
\end{tabular}

Data source: REFLEX, own calculations.

\section{Estimation results}

Match status six months after graduation

In Table 4, we report the estimation results on the likelihood to have a good match in the job six months after graduation. On the basis of the baseline (Model 1a), it is found that the gross variation between countries represents $7.6 \%$ of the overall variation. After inclusion of the Level 1 covariates (Model 1b), however, this variation increases to $8.4 \%$. Hence, it seems that compositional effects underestimate the 
overall importance of the country level in the explanation of the match status at the start of the labour market career. The coefficients of the included covariates are all statistically significant. Women, for example, are found to have a higher likelihood to be overeducated. Theoretical explanations for this outcome are, amongst others, statistical discrimination (Renes and Ridder, 1995) and spatial constraints among married women (Frank, 1978). Nevertheless, many other studies in literature did not note a gender effect (Groot and Maassen van den Brink, 2000; Sloane, 2003). Further, we find that also older graduates have a higher likelihood to be overeducated. Perhaps, the age at which individuals manage to finish their degree works as a negative signal to employers. Another explanation is that older graduates continue in the job which they combined with their education. Those with a degree not providing access to a $\mathrm{PhD}$ then again are found to have a higher probability on a good match. Similar results were also noted in other studies (ROA, 2007; Verhaest and Omey, 2003). A potential explanation is given by differences in the study program duration. Whereas a bachelor's degree takes at least three years, a master's degree can usually be obtained in one or two extra years. Hence, the average number of years of overeducation is likely to be substantially lower among those working below their master's degree than among those working below their bachelor's degree. Also in line with the literature is the positive impact of better study results on the likelihood to find a good match after leaving school (Battu et al., 1999; Büchel and Pollmann-Schult, 2004; Verhaest and Omey, 2010). Finally, our outcomes with respect to the relative quality and orientation of the individual study program are in line with Hypotheses 8 and 10: those with a study program that is of above-average quality or relatively vocationally oriented given their field of study are more likely to have a good match in their first job.

The inclusion of the random effects at the study field level, in Model 2a, results in a substantial drop of the residual variance at the level of the country, from $8.4 \%$ to $4.1 \%$. Also the unexplained variance at the individual level drops and so about $12.3 \%$ of the overall variation in our sample can be attributed to field level effects. These results clearly support our hypothesis that imbalances between the demanded and supplied fields of study on the labour market are an important factor to explain between-country differences in overeducation among graduates (cf. Hypothesis 5). Differences in the demand for certain study fields might, amongst others, be explained by differences in the composition of their study programs. In Model $2 b$, we thus further include the average quality and orientation of each field of study as explanatory variables, which indeed leads to a sizeable drop of the residual variance at the level of the study fields. As expected, graduates from study fields with a high quality and/or vocationally oriented study program have a lower likelihood to be overeducated in their first job after leaving school (cf. Hypotheses 8 and 10). Also interesting is the finding that the between-field effects of the quality or orientation of the study program are substantially higher than their within-field effects. As already stated, this might be explained by signalling effects: employers might only have reliable information regarding the average quality or orientation of the study programs within a certain field of study. Their contribution to the cross-country variation of overeducation, however, is unclear. The residual variance at the level of the country, slightly increases from 4.1 to $5.7 \%$ after the inclusion of these study field-level variables. This suggests that, on 
Table 4: The probability on a good match in the job six months after leaving school: probit multilevel coefficient estimates $(\mathrm{N}=9505)$

\begin{tabular}{|c|c|c|c|c|c|c|c|c|c|}
\hline & Model 1a & Model 1b & Model 2a & Model 2b & Model 3a & Model 3b & Model 3c & Model 3d & Model 3e \\
\hline Intercept & $0.645^{* * *}$ & $0.844 * * *$ & $1.021 * * *$ & $1.022 * * *$ & $1.016^{* * *}$ & $0.941 * * *$ & $1.019 * * *$ & $1.061 * * *$ & $0.710^{* * *}$ \\
\hline Level 1 variables: Graduates & - & & & & & & & & \\
\hline Women & - & $-0.114 * * *$ & $-0.122 * * *$ & $-0.119 * * *$ & $-0.119 * * *$ & $-0.120 * * *$ & $-0.119 * * *$ & $-0.119 * * *$ & $-0.120 * * *$ \\
\hline Age & - & $-0.007 * *$ & $-0.009 * * *$ & $-0.009 * * *$ & $-0.009 * * *$ & $-0.009 * * *$ & $-0.009 * * *$ & $-0.009 * * *$ & $-0.009 * * *$ \\
\hline Degree not providing access to doctorate & - & $0.206^{* * *}$ & $0.109 * * *$ & $0.090 * *$ & $0.088^{* *}$ & $0.091^{* *}$ & $0.094^{* *}$ & $0.090 * *$ & $0.105^{* * *}$ \\
\hline Study results & - & $0.122 * * *$ & $0.124 * * *$ & $0.123 * * *$ & $0.123^{* * *}$ & $0.123 * * *$ & $0.123 * * *$ & $0.123 * * *$ & $0.123 * * *$ \\
\hline Quality study program: deviation from study field average $\left(\mathrm{a}_{1}\right)$ & - & $0.250 * * *$ & $0.256 * * *$ & $0.255^{* * *}$ & $0.255^{* * *}$ & $0.255 * * *$ & $0.255^{* * *}$ & $0.255^{* * *}$ & $0.256^{* * *}$ \\
\hline General orientation: deviation from study field average $\left(b_{1}\right)$ & - & $-0.069 * * *$ & $-0.082 * * *$ & $-0.083 * * *$ & $-0.083 * * *$ & $-0.083 * * *$ & $-0.083 * * *$ & $-0.083 * * *$ & $-0.081^{* * *}$ \\
\hline \multicolumn{10}{|l|}{ Level 2 variable: Fields of study } \\
\hline Quality study program: field of study average $\left(\mathrm{a}_{2}\right)$ & - & - & - & $0.471 * * *$ & - & $0.461 * * *$ & $0.474 * * *$ & $0.470 * * *$ & - \\
\hline General orientation: field of study average $\left(b_{2}\right)$ & - & - & - & $-0.403^{* * *}$ & - & $-0.408 * * *$ & $-0.405^{* * *}$ & $-0.404 * * *$ & - \\
\hline Quality study program: deviation from country average $\left(\mathrm{a}_{2}\right)$ & - & - & - & - & $0.480 * * *$ & - & - & - & $0.476^{* * *}$ \\
\hline General orientation: deviation from country average $\left(b_{2}\right)$ & - & - & - & - & $-0.409 * * *$ & - & - & - & $-0.392 * * *$ \\
\hline \multicolumn{10}{|l|}{ Level 3 variables: Countries } \\
\hline Quality study program: country average $\left(\mathrm{a}_{3}\right)$ & - & - & - & - & 0.304 & - & - & - & 0.226 \\
\hline General orientation: country average $\left(b_{3}\right)$ & - & - & - & - & -0.275 & - & - & - & $-0.432 * *$ \\
\hline Output gap 2000 & - & - & - & - & - & 0.056 & - & - & $0.133^{* * *}$ \\
\hline Relative oversupply highly educated workers & - & - & - & - & - & - & $-0.240 * * *$ & - & $-0.291 * * *$ \\
\hline Degree of employment protection & - & - & - & - & - & - & - & -0.018 & 0.054 \\
\hline \multicolumn{10}{|l|}{ Chi²-tests } \\
\hline $\operatorname{Chi}^{2}\left(\mathrm{a}_{1}=\mathrm{a}_{2}\right)$ & - & - & - & $6.6^{* *}$ & $6.6^{*}$ & $5.9 * *$ & $7.2^{* * *}$ & $6.5^{* *}$ & $6.3^{* *}$ \\
\hline $\mathrm{Chi}^{2}\left(\mathrm{~b}_{1}=\mathrm{b}_{2}\right)$ & - & - & - & $12.2^{* * *}$ & $11.3^{* * *}$ & $12.6^{* * *}$ & $13.4^{* * *}$ & $12.2^{* * *}$ & $10.4^{* * *}$ \\
\hline $\operatorname{Chi}^{2}\left(\mathrm{a}_{2}=\mathrm{a}_{3}\right)$ & - & - & - & - & 0.4 & - & - & - & 1.8 \\
\hline $\mathrm{Chi}^{2}\left(\mathrm{~b}_{2}=\mathrm{b}_{3}\right)$ & - & - & - & - & 0.2 & - & - & - & 0.0 \\
\hline \multicolumn{10}{|l|}{ Variance decomposition } \\
\hline Unexplained variance level 1: Graduates & 0.924 & 0.847 & 0.774 & 0.767 & 0.777 & 0.765 & 0.776 & 0.768 & 0.785 \\
\hline Unexplained variance level 2: Fields of study & - & - & 0.123 & 0.043 & 0.043 & 0.042 & 0.044 & 0.043 & 0.044 \\
\hline Unexplained variance level 3: Countries & 0.076 & 0.084 & 0.041 & 0.057 & 0.055 & 0.055 & 0.025 & 0.057 & 0.009 \\
\hline Explained variance & - & 0.069 & 0.062 & 0.133 & 0.125 & 0.138 & 0.155 & 0.132 & 0.163 \\
\hline \multicolumn{10}{|l|}{ Model Diagnostics } \\
\hline Log likelihood & -5316.7 & -5126.6 & -4987.1 & -4956.8 & -4956.5 & -4956.4 & -4952.1 & -4956.8 & -4947.8 \\
\hline Condition number & 1.4 & 64.8 & 68.2 & 67.3 & 154.1 & 86.9 & 77.2 & 152.9 & 179.0 \\
\hline
\end{tabular}


average, the countries with rather successful educational institutions have other unmeasured characteristics which are less beneficial for the match of graduates.

Finally, we also include variables that are measured at the country level. In Model 3a, the study-field level effects of the characteristics of the programs are further decomposed in a country-level effect and a residual effect. Yet, this does not clarify much: although the coefficients of both country-level variables are statistically insignificant, also the hypothesis that their country-level effects are not different from their study field-effects cannot be rejected. Further, we account for differences in the output gap, the relative oversupply of highly educated workers and the strictness of the employment protection legislation. On the basis of the specifications that include just one of these country-level variables (cf. Model 3b, 3c and 3d), we only note a statistically significant impact of the relative oversupply of highly educated workers. The inclusion of this variable is found to explain more than half of the remaining residual variance at the country level (cf. Hypothesis 3). Moreover, once we control jointly for all country-level variables (cf. Model 3e), also the coefficient of the output gap becomes statistically significant and the residual country-level variance further drops to about 1\% (cf. Hypothesis 1). Cross-country differences in the incidence of overeducation six months after graduation are thus explained by cyclical fluctuations as well as by more structural gaps between demand and supply. The strictness of the employment protection legislation, however, is not found to be a decisive factor. While the outcomes with respect to the business

cycle and the employment protection legislation are in line with our hypotheses, they seem to contradict those of previous studies in the literature (cf. Section I). Probably, these variables play a different role with respect to the persistence of overeducation and the match status at later points in the career.

\section{Transitions between the first and the current job}

In Table 5 and 6, we report the results regarding the match status in the job five years after graduation conditional on the match status in the first job. On the basis of the baseline model (Model 1a), we note that only $3.3 \%$ of the overall variation in the probability to stay in a good match can be attributed to country-level effects. After inclusion of the individual-level variables (Model 1b), this proportion slightly increases to $3.7 \%$. With respect to the probability to make the transition from overeducation to a good match, these figures are respectively 5.8 and 6.5\%. It thus seems that country-level effects play a more important role at the start of the career than later on. For most of the individual-level variables, results are in line with those on the match status in the first job. The unfavourable match status of women, for example, is largely confirmed. Whereas women have a higher likelihood to be overeducated immediately after graduation, they are not more likely to use their overeducation status as a stepping stone. And if they manage to find a good match, they are more likely to fall back into overeducation thereafter. Those with a degree not providing access to a $\mathrm{PhD}$ do not only have a better match to start with, but are also found to have a higher probability to stay in a good match or to get a good match, whereas older graduates and those with lower grades, are less likely to get out of overeducation. Further, in line with Hypothesis 8 , we find that those with a study program that is of above-average quality within their field of study are more 
Table 5: The probability to stay in a good match: probit multilevel coefficient estimates $(\mathrm{N}=6495)$

\begin{tabular}{|c|c|c|c|c|c|c|c|c|c|}
\hline & Model 1a & Model 1b & Model 2a & Model 2b & Model 3a & Model 3b & Model 3c & Model 3d & Model 3e \\
\hline Intercept & $1.690 * * *$ & $1.559 * * *$ & $1.583 * * *$ & $1.637 * * *$ & $1.637 * * *$ & $1.621 * * *$ & $1.629 * * *$ & $1.719 * * *$ & $1.649 * * *$ \\
\hline Level 1 variables & - & & & & & & & & \\
\hline Women & - & $-0.268 * * *$ & $-0.271^{* * *}$ & $-0.272 * * *$ & $-0.271 * * *$ & $-0.272 * * *$ & $-0.269 * * *$ & $-0.271 * * *$ & $-0.265 * * *$ \\
\hline Age & - & 0.007 & 0.006 & 0.005 & 0.006 & 0.005 & 0.005 & 0.005 & 0.004 \\
\hline Degree not providing access to doctorate & - & $0.172 * *$ & $0.161^{* *}$ & 0.105 & 0.111 & 0.107 & $0.117^{*}$ & 0.099 & $0.154^{*}$ \\
\hline Study results & - & 0.044 & 0.044 & 0.041 & 0.040 & 0.041 & 0.040 & 0.041 & 0.038 \\
\hline Quality study program: deviation from study field average $\left(\mathrm{a}_{1}\right)$ & - & $0.156^{* * *}$ & $0.157 * * *$ & $0.161 * * *$ & $0.160 * * *$ & $0.161 * * *$ & $0.162 * * *$ & $0.161^{* * *}$ & $0.162 * * *$ \\
\hline General orientation: deviation from study field average $\left(b_{1}\right)$ & - & -0.031 & -0.032 & -0.035 & -0.034 & -0.035 & -0.035 & -0.036 & -0.031 \\
\hline \multicolumn{10}{|l|}{ Level 2 variable: Fields of study } \\
\hline Quality study program: field of study average $\left(\mathrm{a}_{2}\right)$ & - & - & - & $0.250 * * *$ & - & $0.245 * * *$ & $0.263^{* * *}$ & $0.250 * * *$ & - \\
\hline General orientation: field of study average $\left(b_{2}\right)$ & - & - & - & $-0.223^{* *}$ & - & $-0.224 * *$ & $-0.243^{* * *}$ & $-0.231^{* *}$ & - \\
\hline Quality study program: deviation from country average $\left(\mathrm{a}_{2}\right)$ & - & - & - & - & $0.257 * * *$ & - & - & - & $0.267 * * *$ \\
\hline General orientation: deviation from country average $\left(b_{2}\right)$ & - & - & - & - & $-0.183 *$ & - & - & - & $-0.166 *$ \\
\hline \multicolumn{10}{|l|}{ Level 3 variables: Countries } \\
\hline Quality study program: country average $\left(\mathrm{a}_{3}\right)$ & - & - & - & - & $0.307^{*}$ & - & - & - & $0.331^{* *}$ \\
\hline General orientation: country average $\left(b_{3}\right)$ & - & - & - & - & $-0.417 * *$ & - & - & - & $-0.609 * * *$ \\
\hline Output gap 2000 & - & - & - & - & - & 0.017 & - & - & 0.059 \\
\hline Relative oversupply highly educated workers & - & - & - & - & - & - & $-0.108 * *$ & - & $-0.158 * * *$ \\
\hline Degree of employment protection & - & - & - & - & - & - & - & -0.037 & -0.031 \\
\hline \multicolumn{10}{|l|}{ Chi²-tests } \\
\hline $\operatorname{Chi}^{2}\left(a_{1}=a_{2}\right)$ & - & - & - & 1.1 & 1.0 & 0.9 & 1.4 & 1.1 & 1.2 \\
\hline $\mathrm{Chi}^{2}\left(\mathrm{~b}_{1}=\mathrm{b}_{2}\right)$ & - & - & - & $4.0^{* *}$ & 2.1 & $4.1^{* *}$ & $5.1^{* *}$ & $4.3^{* *}$ & 1.7 \\
\hline $\operatorname{Chi}^{2}\left(\mathrm{a}_{2}=\mathrm{a}_{3}\right)$ & - & - & - & - & 0.1 & - & - & - & 0.1 \\
\hline $\mathrm{Chi}^{2}\left(\mathrm{~b}_{2}=\mathrm{b}_{3}\right)$ & - & - & - & - & 1.1 & - & - & - & $5.5^{* *}$ \\
\hline \multicolumn{10}{|l|}{ Variance decomposition } \\
\hline Unexplained variance level 1: school leavers & 0.967 & 0.921 & 0.917 & 0.914 & 0.909 & 0.914 & 0.915 & 0.915 & 0.912 \\
\hline Unexplained variance level 2: study programs & - & - & 0.008 & 0.000 & 0.000 & 0.000 & 0.000 & 0.000 & 0.000 \\
\hline Unexplained variance level 3: countries & 0.033 & 0.037 & 0.034 & 0.023 & 0.021 & 0.023 & 0.015 & 0.022 & 0.005 \\
\hline Explained variance & - & 0.041 & 0.041 & 0.063 & 0.069 & 0.063 & 0.069 & 0.063 & 0.083 \\
\hline \multicolumn{10}{|l|}{ Model Diagnostics } \\
\hline Log likelihood & -1196.8 & -1168.2 & -1167.9 & -1155.2 & -1154.6 & -1155.1 & -1153.3 & -1155.1 & -1150.0 \\
\hline Condition number & 1.2 & 118.0 & 121.0 & 136.8 & 141.6 & 140.9 & 153.3 & 180.2 & 239.8 \\
\hline
\end{tabular}


Table 6: The probability to make the transition from overeducation to a good match: probit multilevel coefficient estimates ( $\mathrm{N}=2239)$

\begin{tabular}{|c|c|c|c|c|c|c|c|c|c|}
\hline & Model 1a & Model 1b & Model 2a & Model 2b & Model 3a & Model 3b & Model 3c & Model 3d & Model 3e \\
\hline Intercept & $0.151^{* *}$ & $0.515^{* *}$ & $0.423 * *$ & $0.422 * *$ & $0.427 * *$ & 0.272 & $0.422 * *$ & 0.240 & 0.214 \\
\hline Level 1 variables & - & & & & & & & & \\
\hline Women & - & 0.034 & 0.039 & 0.067 & 0.068 & 0.061 & 0.067 & 0.066 & 0.067 \\
\hline Age & - & $-0.012 * *$ & $-0.011^{*}$ & $-0.012^{* *}$ & $-0.012 * *$ & $-0.013 * *$ & $-0.012 * *$ & $-0.012 * *$ & $-0.013^{* *}$ \\
\hline Degree not providing access to doctorate & - & 0.094 & $0.130 *$ & $0.160 * *$ & $0.165^{* *}$ & $0.165^{* *}$ & $0.160 * *$ & $0.167 * *$ & $0.173 * *$ \\
\hline Study results & - & $0.078 * *$ & $0.080 * *$ & $0.080 * *$ & $0.080 * *$ & $0.080 * *$ & $0.080 * *$ & $0.080 * *$ & $0.079 * *$ \\
\hline Quality study program: deviation from study field average $\left(\mathrm{a}_{1}\right)$ & - & $0.138 * * *$ & $0.143 * * *$ & $0.146 * * *$ & $0.146^{* * *}$ & $0.147 * * *$ & $0.146^{* * *}$ & $0.146^{* * *}$ & $0.148 * * *$ \\
\hline General orientation: deviation from study field average $\left(b_{1}\right)$ & - & $0.096 * * *$ & $0.092 * * *$ & $0.096 * * *$ & $0.097 * * *$ & $0.096 * * *$ & $0.096 * * *$ & $0.097 * * *$ & $0.097 * * *$ \\
\hline \multicolumn{10}{|l|}{ Level 2 variable: Fields of study } \\
\hline Quality study program: field of study average $\left(\mathrm{a}_{2}\right)$ & - & - & - & $0.318 * * *$ & - & $0.261^{* *}$ & $0.317^{* * *}$ & $0.320 * * *$ & - \\
\hline General orientation: field of study average $\left(b_{2}\right)$ & - & - & - & $0.262 * *$ & - & $0.221 *$ & $0.262 * *$ & $0.276 * *$ & - \\
\hline Quality study program: deviation from country average $\left(\mathrm{a}_{2}\right)$ & - & - & - & - & $0.317^{* *}$ & - & - & - & $0.313^{* *}$ \\
\hline General orientation: deviation from country average $\left(b_{2}\right)$ & - & - & - & - & $0.307 * *$ & - & - & - & $0.299 * *$ \\
\hline \multicolumn{10}{|l|}{ Level 3 variables: Countries } \\
\hline Quality study program: country average $\left(\mathrm{a}_{3}\right)$ & - & - & - & - & 0.419 & - & - & - & 0.202 \\
\hline General orientation: country average $\left(b_{3}\right)$ & - & - & - & - & 0.007 & - & - & - & -0.020 \\
\hline Output gap 2000 & - & - & - & - & - & $0.132 * *$ & - & - & $0.155^{* * *}$ \\
\hline Relative oversupply highly educated workers & - & - & - & - & - & - & 0.004 & - & -0.077 \\
\hline Degree of employment protection & - & - & - & - & - & - & - & 0.083 & 0.016 \\
\hline \multicolumn{10}{|l|}{ Chi'tests } \\
\hline $\operatorname{Chi}^{2}\left(\mathrm{a}_{1}=\mathrm{a}_{2}\right)$ & - & - & - & 2.1 & 1.8 & 0.9 & 2.1 & 2.2 & 1.6 \\
\hline $\mathrm{Chi}^{2}\left(\mathrm{~b}_{1}=\mathrm{b}_{2}\right)$ & - & - & - & 1.6 & 2.2 & 1.0 & 1.6 & 1.9 & 2.0 \\
\hline $\operatorname{Chi}^{2}\left(\mathrm{a}_{2}=\mathrm{a}_{3}\right)$ & - & - & - & - & 0.1 & - & - & - & 0.2 \\
\hline $\mathrm{Chi}^{2}\left(\mathrm{~b}_{2}=\mathrm{b}_{3}\right)$ & - & - & - & - & 0.9 & - & - & - & 1.3 \\
\hline \multicolumn{10}{|l|}{ Variance decomposition } \\
\hline Unexplained variance level 1: school leavers & 0.942 & 0.904 & 0.857 & 0.862 & 0.862 & 0.862 & 0.862 & 0.861 & 0.867 \\
\hline Unexplained variance level 2: study programs & - & - & 0.066 & 0.053 & 0.052 & 0.054 & 0.053 & 0.053 & 0.052 \\
\hline Unexplained variance level 3: countries & 0.058 & 0.065 & 0.045 & 0.043 & 0.041 & 0.023 & 0.043 & 0.042 & 0.019 \\
\hline Explained variance & - & 0.031 & 0.031 & 0.041 & 0.045 & 0.060 & 0.042 & 0.043 & 0.062 \\
\hline \multicolumn{10}{|l|}{ Model Diagnostics } \\
\hline Log likelihood & -1504.4 & -1482.8 & -1468.9 & -1464.5 & -1463.9 & -1462.1 & -1464.5 & -1464.2 & -1461.1 \\
\hline Condition number & 1.3 & 91.2 & 95.9 & 98.6 & 134.6 & 120.5 & 98.7 & 156.6 & 186.7 \\
\hline
\end{tabular}


likely to stay in a good match as well as to make the transition from overeducation to a good match. Finally, the results with respect to the orientation of the study program are in line with Hypothesis 10: whereas those with a relatively generally oriented study program given their field of study are less likely to have a good match in their first job, they are more likely to use overeducation as a stepping stone.

Also the study field-level effects are found to be less important for the explanation of the transitions between the two time points compared to the match status in the first job (cf. Model 2a). With respect to the probability to stay in a good match, they explain even less than $1 \%$ of the overall variance. Hence, the unexplained country-level variance of this probability hardly changes after the inclusion of these random effects at the level of the field of study. Imbalances in the demand and supply of study fields are found to be a bit more important for the explanation of country-level variance of the probability to get out of overeducation: the unexplained country-level variance for this probability drops from 6.5 to $4.5 \%$. In Model $2 \mathrm{~b}$, we further add the average quality and orientation of each study field as explanatory variables. The results on the average quality and selectivity of the study program confirm Hypothesis 8: school leavers from subjects with a study program of above-average quality are more likely to stay in a good match or to make the transition from overeducation to a good match. Generally oriented study fields result in a lower probability to keep a good match, but also in a higher probability to use overeducation as a stepping stone (cf. Hypothesis 10). The inclusion of these variables result in a further decrease of the unexplained country-level variance of the probability to stay in a good match from 3.4 to $2.3 \%$. With respect to the probability to make the transition from overeducation to a good match, however, this variance hardly changes.

Further decomposition of the subject-level effects confirms that the educational institutions primarily contribute to cross-country differences in the probability to stay in a good match (cf. Model 3a). The likelihood to stay in a good match is higher in countries with a high-quality and vocational education system. Moreover, the country-level effect of the vocational orientation of the program is found to be even more pronounced than its study field-level effect (cf. Model 3e). Conversely, with respect to the persistence of overeducation, none of the country-level effects is statistically significant. Nevertheless, also the null hypothesis that these country-level effects are not different from the study field-level effects is rejected. Finally, also with respect to the effect of the other country-level variables, outcomes differ between the two conditional probabilities. Whereas particularly structural differences in the demand and supply explain the between-country variation of the probability to stay in a good match, rather cyclical factors influence the probability to get out of overeducation. Again, we find no evidence that the strictness of the employment protection legislation is important for the explanation of the match status.

Match status five years after graduation

We end with an analysis of the determinants of the match status five years after graduation. Our estimates confirm that the importance of country-level effects decrease over the career: after control for the indivi- 
dual-level variables (Model 1b), we find that about 5.3\% of the overall unexplained variance of the match status five years after graduation can be attributed to the country level. The only individual-level variable with a statistically insignificant coefficient is the orientation of the program. The negative impact of this orientation on the match status in the first employment is thus compensated by the positive impact on the probability that overeducation serves as a stepping stone.

Also the importance of the study field-level effects falls over the career: on the basis of Model 3a, we find that $6.2 \%$ of the overall variance in the match status five years after graduation is attributed to these effects compared to $12.3 \%$ for the first job. Hypothesis 6, which states that imbalances between the demanded and supplied subjects are particularly important at labour market entry, is thus confirmed. Nevertheless, the study field-level effects are still responsible for a drop of the share of the unexplained country-level variance to $3.4 \%$. In Model 3b, we further include study field-level variables. Given the results on the match in the first job and the transition probabilities, it is not surprising to find again that the between-field effect of the quality of the program is larger than the within-study field effect. Moreover, whereas the within-field effect of the program orientation becomes statistically insignificant five years after graduation, this is not the case for the between-field effect. So, it seems that school leavers from generally oriented fields of study need more than five years to catch up with those from more vocationally oriented fields of study. However, the program characteristics again are found to contribute little to the between-country variance: the share of the unexplained country-level variance only drops from $3.4 \%$ to $3.1 \%$.

With respect to the country-level variables, the most convincing evidence is noted for the relative oversupply of highly educated workers. Introduction of this variable into the model results in a drop of the unexplained country-level variance from 3.1\% to 1.6\% (cf. Model 3c). Further inclusion of the remaining country-level variables in Model 3e results in a complete reduction of the residual variance at the country level. Like for the first job, we note a positive impact from the output gap, a negative impact from a relative oversupply of educated workers and from a generally oriented educational system, and no impact from the strictness of the employment protection legislation. Moreover, like with respect to the probability to stay in a good match, the country-level effect of the orientation of the program is found to be more pronounced than the study field- and individual-level effects. Finally, also the effect of the quality and selectivity of the educational system is now found to be statistically significant.

Finally, we also report estimates on the basis of some alternative model specifications. The match in the current job might not just be affected by the business cycle at the time of labour market entry, but also by the economic conditions in later years. As shown in Table 8, the coefficient of the output gap during the year 2005 has an unexpected negative sign if no other country-level variables are controlled for. Once we also control for the output gap during the year 2000, however, the coefficient becomes statistically insignificant $^{\mathrm{ix}}$. Accordingly, the evidence with respect to Hypothesis 2, which states that the business cycle is more important to explain overeducation at the start of the career than later on, is nuanced. Although the 
Table 7: The probability on a good match in the job five years after leaving school: probit multilevel coefficient estimates $(\mathrm{N}=11184)$

\begin{tabular}{|c|c|c|c|c|c|c|c|c|c|}
\hline & Model 1a & Model 1b & Model 2a & Model 2b & Model 3a & Model 3b & Model 3c & Model 3d & Model 3e \\
\hline Intercept & $1.027 * * *$ & $1.319 * * *$ & $1.400 * * *$ & $1.409 * * *$ & $1.409 * * *$ & $1.301 * * *$ & $1.409 * * *$ & $1.410^{* * *}$ & $1.231^{* * *}$ \\
\hline Level 1 variables: Graduates & - & & & & & & & & \\
\hline Women & - & $-0.112^{* * *}$ & $-0.108 * * *$ & $-0.101^{* * *}$ & $-0.101 * * *$ & $-0.103^{* * *}$ & $-0.100 * * *$ & $-0.101^{* * *}$ & $-0.099 * * *$ \\
\hline Age & - & $-0.009 * * *$ & $-0.011^{* * *}$ & $-0.010^{* * *}$ & $-0.010 * * *$ & $-0.011^{* * *}$ & $-0.010 * * *$ & $-0.010^{* * *}$ & $-0.012 * * *$ \\
\hline Degree not providing access to doctorate & - & $0.199 * * *$ & $0.155^{* * *}$ & $0.141^{* * *}$ & $0.141^{* * *}$ & $0.143^{* * *}$ & $0.141^{* * *}$ & $0.141^{* * *}$ & $0.149 * * *$ \\
\hline Study results & - & $0.110^{* * *}$ & $0.111^{* * *}$ & $0.109 * * *$ & $0.109 * * *$ & $0.109 * * *$ & $0.109 * * *$ & $0.109 * * *$ & $0.109 * * *$ \\
\hline Quality study program: deviation from study field average $\left(a_{1}\right)$ & - & $0.255^{* * *}$ & $0.259 * * *$ & $0.259 * * *$ & $0.259 * * *$ & $0.259 * * *$ & $0.259 * * *$ & $0.259 * * *$ & $0.259 * * *$ \\
\hline General orientation: deviation from study field average $\left(b_{1}\right)$ & - & 0.003 & -0.003 & -0.004 & -0.004 & -0.003 & -0.004 & -0.004 & -0.003 \\
\hline \multicolumn{10}{|l|}{ Level 2 variable: Fields of study } \\
\hline Quality study program: field of study average $\left(\mathrm{a}_{2}\right)$ & - & - & - & $0.435^{* * *}$ & - & $0.414^{* * *}$ & $0.444^{* * *}$ & $0.435 * * *$ & - \\
\hline General orientation: field of study average $\left(b_{2}\right)$ & - & - & - & $-0.159 * *$ & - & $-0.170 * *$ & $-0.171 * *$ & $-0.159 * *$ & - \\
\hline Quality study program: deviation from country average $\left(\mathrm{a}_{2}\right)$ & - & - & - & - & $0.444^{* * *}$ & - & - & - & $0.447 * * *$ \\
\hline General orientation: deviation from country average $\left(b_{2}\right)$ & - & - & - & - & $-0.147^{*}$ & - & - & - & $-0.148^{*}$ \\
\hline \multicolumn{10}{|l|}{ Level 3 variables: Countries } \\
\hline Quality study program: country average $\left(\mathrm{a}_{3}\right)$ & - & - & - & - & $0.393 *$ & - & - & - & $0.266 * * *$ \\
\hline General orientation: country average $\left(b_{3}\right)$ & - & - & - & - & -0.225 & - & - & - & $-0.372 * * *$ \\
\hline Output gap 2000 & - & - & - & - & & $0.080 *$ & - & - & $0.142 * * *$ \\
\hline Relative oversupply highly educated workers & - & - & - & - & - & - & $-0.153 * * *$ & - & $-0.213^{* * *}$ \\
\hline Degree of employment protection & - & - & - & - & - & - & - & 0.000 & 0.005 \\
\hline \multicolumn{10}{|l|}{ Chi'2-tests } \\
\hline $\operatorname{Chi}^{2}\left(a_{1}=a_{2}\right)$ & - & - & - & $6.4^{* *}$ & $6.2^{* *}$ & $4.9 * *$ & $7.3 * * *$ & $6.4^{* *}$ & $6.6^{* *}$ \\
\hline $\mathrm{Chi}^{2}\left(\mathrm{~b}_{1}=\mathrm{b}_{2}\right)$ & - & - & - & $4.2^{* *}$ & $3.2 *$ & $5.0 * *$ & $5.2 * *$ & $4.2^{* *}$ & $3.4^{*}$ \\
\hline $\operatorname{Chi}^{2}\left(\mathrm{a}_{2}=\mathrm{a}_{3}\right)$ & - & - & - & - & 0.1 & - & - & - & 2.4 \\
\hline $\mathrm{Chi}^{2}\left(\mathrm{~b}_{2}=\mathrm{b}_{3}\right)$ & - & - & - & - & 0.1 & - & - & - & $3.2^{*}$ \\
\hline \multicolumn{10}{|l|}{ Variance decomposition } \\
\hline Unexplained variance level 1: Graduates & 0.959 & 0.879 & 0.840 & 0.843 & 0.843 & 0.840 & 0.847 & 0.843 & 0.848 \\
\hline Unexplained variance level 2: Fields of study & - & - & 0.062 & 0.023 & 0.023 & 0.023 & 0.024 & 0.023 & 0.022 \\
\hline Unexplained variance level 3: Countries & 0.041 & 0.053 & 0.034 & 0.031 & 0.030 & 0.024 & 0.016 & 0.031 & 0.000 \\
\hline Explained variance & - & 0.068 & 0.064 & 0.103 & 0.103 & 0.112 & 0.112 & 0.103 & 0.129 \\
\hline \multicolumn{10}{|l|}{ Model Diagnostics } \\
\hline Log likelihood & -4783.4 & -4613.9 & -4563.1 & -4536.6 & -4536.5 & -4535.2 & -4533.2 & -4536.6 & -4522.6 \\
\hline Condition number & 1.4 & 69.5 & 73.4 & 77.4 & 139.6 & 93.2 & 90.4 & 146.3 & 202.5 \\
\hline
\end{tabular}


Table 8: The probability on a good match five years after leaving school (alternative model specifications): probit multilevel coefficient estimates $(\mathrm{N}=11184$ )

\begin{tabular}{|c|c|c|c|c|c|c|c|c|c|c|}
\hline & Model 4a & Model 4b & Model 4c & Model 4d & Model 4e & Model 4f & Model 4g & Model 4h & Model 4i & Model 4j \\
\hline \multicolumn{11}{|l|}{ Level 3 variables } \\
\hline Output gap 2000 & - & - & $0.119 * * *$ & - & - & - & - & $0.147 * * *$ & - & $0.081 * *$ \\
\hline Output gap 2005 & $-0.111^{* * *}$ & $-0.083 * *$ & -0.024 & - & - & - & - & - & - & - \\
\hline Unemployment rate 2000 & - & - & - & -0.011 & -0.016 & - & - & - & - & - \\
\hline Relative unemployment gap 2000 & - & - & - & - & - & -0.354 & $-0.471^{*}$ & 0.164 & - & - \\
\hline Relative oversupply highly ed. work.. & - & $-0.113^{* *}$ & $-0.188 * * *$ & - & $-0.159 * * *$ & - & $-0.164^{* * *}$ & $-0.208^{* * *}$ & - & - \\
\hline Absolute share of highly ed. individ. & - & - & - & - & - & - & - & - & -1.688 & -1.090 \\
\hline \multicolumn{11}{|l|}{ Variance decomposition } \\
\hline Unexpl. var. level 1: school leavers & 0.852 & 0.851 & 0.847 & 0.842 & 0.847 & 0.842 & 0.846 & 0.848 & 0.843 & 0.839 \\
\hline Unexpl. var. level 2: study programs & 0.025 & 0.026 & 0.025 & 0.023 & 0.024 & 0.023 & 0.025 & 0.025 & 0.023 & 0.023 \\
\hline Unexpl. var. level 3: countries & 0.016 & 0.009 & 0.000 & 0.030 & 0.014 & 0.028 & 0.012 & 0.000 & 0.027 & 0.025 \\
\hline Explained variance & 0.107 & 0.115 & 0.127 & 0.104 & 0.115 & 0.107 & 0.118 & 0.127 & 0.107 & 0.113 \\
\hline \multicolumn{11}{|l|}{ Model Diagnostics } \\
\hline Log likelihood & -4533.1 & -4530.6 & -4524.7 & -4536.4 & -4532.7 & -4536.1 & -4531.8 & -4524.8 & -4535.8 & -4534.8 \\
\hline Condition number & 99.8 & 112.3 & 150.0 & 114.6 & 124.2 & 236.4 & 226.5 & 279.6 & 885.0 & 817.7 \\
\hline
\end{tabular}

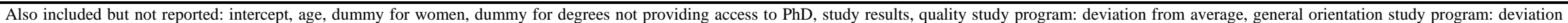
from average, quality of study program: average, and quality of study program: average;

Data source: REFLEX, own calculations; *: $\mathrm{p}<0.10,{ }^{* *}: \mathrm{p}<0.05, * * *: \mathrm{p}<0.01$. 
match status of more experienced workers indeed seems to be unaffected by business cycle at the time of observation, there is a scarring effect from the business cycle at the time of graduation. As additional robustness checks, we also execute estimates on the basis of the unemployment rate and the relative unemployment gap in 2000. The relative unemployment gap is found to have a statistically significant negative effect once we control for the relative oversupply of skilled workers. However, after further inclusion of the output gap as explanatory variable, its coefficient becomes statistically insignificant. Similarly, the coefficient of the unemployment rate is never statistically significant ${ }^{10}$. So, the reason why other studies failed to find a relation between the business cycle and the incidence of overeducation seems to be twofold: they used the 'wrong' business cycle indicator and measured at the 'wrong' point in time. In a last group of models, we include the absolute share of highly educated individuals instead of the relative oversupply variable. Yet, in line with Hypothesis 4, we find no indications that the countries with a highly educated population are also those with the highest likelihood to be overeducated.

\section{Conclusions}

In this study, we focussed on cross-country differences in overeducation and its persistence among graduates in their five years on the labour market. For this analysis, we used data from the REFLEX study regarding the transition from education to work in fifteen European countries and Japan. These graduates

finished their education during the academic year 1999/2000 and were questioned five years later, in 2005. By means of multi-level techniques, we analysed the factors that contribute to the cross-country variation in the incidence of overeducation in the job six months after graduation, the job five years after graduation and the transition probabilities between these two points in time.

First of all, our results indicated that a substantial part of the cross-country variation in overeducation in the first job can be attributed to differences in the imbalance between the demanded and supplied fields of study on the labour market. For the employment five years after graduation, however, this factor seems to be less important, perhaps because workers resolve their lack of the study field-specific skills by additional training. Also the quality and orientation of the study program are important, primarily for the explanation of within-country differences in overeducation. We noted a positive impact of the quality of the program on the probability to find a good match in the first job, the probability to stay in a good match as well as on the probability to use overeducation as a stepping stone to a good match. This seems to support the heterogeneous skills hypothesis which states that those who are formally overeducated just lack the necessarily skills (see, e.g., Allen and van der Velden, 2001). The results with respect to the orientation of the study program are more nuanced. Those with a generally oriented program have a lower likelihood to have a good match in the first job and to stay in a good match. Their ability to use overeducation as a stepping stone, however, was found to be higher. These findings are consistent with the view that vocational systems are successful in the acquisition of specific skills, whereas general systems particularly result in the acquisition of generic skills. Moreover, they are also in line with segmentation theories (Doeringer and Piore, 1971; Dekker et al., 2002): generally educated individuals enter predominantly in internal 
labour markets which offer internal promotions; vocationally educated individuals enter either in a highly protected occupational labour market or get stuck in the secondary segment. The importance of these institutions for cross-country differences in overeducation, however, is not completely obvious and requires further investigation. Only with respect to the probability to stay in a good match, we noted clear support for the hypothesis that these characteristics contribute to the cross-country variation.

The two other factors that were found to be important for the explanation of cross-country differences in overeducation are the business cycle and the relative supply of educated workers. Graduates that enter the labour market during a recession and/or face fierce competition from other highly educated individuals are much more likely to be overeducated in their first job. Moreover, the stance of the business cycle at the time graduation also influences the extent to which individuals manage to make the transition from overeducation to a good match. Hence, entering the labour market during a recession affects the quality of the match up to five years later. With respect to the probability to stay in a good match, particularly structural factors are important: a structural oversupply of highly educated individuals results in higher match insecurity. Remarkable is also the finding that overeducation and its persistence are not related to the absolute share of highly educated individuals in a country. Put differently, the countries with the highest investments in education are not necessarily those who face a structural oversupply of educated workers. This seems to confirm the hypothesis that supply might create its own demand. Finally, conversely to a previous study by Di Pietro (2002), we found no evidence on a positive relation between the incidence of overeducation and the strictness of the employment protection legislation.

\section{References}

Acemoglu, D. (1998), 'Why do new technologies complement skills? Directed technical change and wage inequality’, Quarterly Journal of Economics, 113, 1055-1089.

Allen, J., and van der Velden, R. (2001), 'Educational mismatches versus skill mismatches: effects on wages, job satisfaction, and on-the-job search', Oxford Economic Papers, 53 (3), 434-452.

Allen, J., and van der Velden, R. (2007), The Flexible Professional in The Knowledge Society: General Results of the REFLEX Project, 283p.

Barro, R., and Lee, J. (2001), 'International data on educational attainment: updates and implications', Oxford Economic Papers, 53 (3), 541-563.

Battu, H., Belfield, C., and Sloane, P. (1999), 'Overeducation among graduates: a cohort view’, Education Economics, 7 (1), 21-39.

Berg, I. (1970), Education and Jobs: The Great Training Robbery, New York: Praeger Publishers,

Büchel, F., and Mertens, A. (2004), 'Overeducation, undereducation, and the theory of career mobility', Applied Economics, 36, 803-816.

Dekker, R., de Grip, A., and Heijke, H. (2002), 'The effects of training and overeducation on career mobility in a segmented labour market', International Journal of Manpower, 23 (2), 106-125.

Devereux, P. (2000), 'Task assignment over the business cycle’, Journal of Labor Economics, 18 (1), 98- 
124.

Devereux, P. (2002), 'Occupational upgrading and the business cycle’, Labour, 16 (3), 423-452.

Di Pietro, G. (2002), 'Technological change, labor markets and 'low skill, low-technology traps’', Technological Forecasting \& Social Change, 69, 885-895.

Di Pietro, G., and Cutillo, A. (2006), 'University quality and labour market outcomes in Italy', Labour, 20 (1), 37-62.

Doeringer, P., and Piore, M. (1971), Internal Labor Markets and Manpower Analysis, Lexington Books.

Dolado, J., Jansen, M., and Jimeno, J. (2009). 'On-the-job search in a matching model with heterogeneous jobs and workers', Economic Journal, 119 (534), 200-228.

Dolton, P., and Vignoles, A. (2000), 'The incidence and effects of overeducation in the U.K. graduate labour market', Economics of Education Review, 19 (2), 179-180.

Frank, R. (1978), 'Why women earn less: the theory and estimation of differential overqualification', American Economic Review, 68 (3), 360-373.

Freeman, R. (1976), The Overeducated American, New York: Academia Press.

Frenette, M. (2004), 'The overqualified Canadian graduate: the role of the academic program in the incidence, persistence, and economic returns to overqualification', Economics of Education Review, 23 (1), 29-45.

Gautier, P. (2002), 'Search externalities in a model with heterogeneous jobs and workers', Economica, 273, 21-40.

Green, P., McIntosh, S., and Vignoles, A. (2002), 'The utilization of education and skills: evidence from Britain’, The Manchester School, 70 (6), 792-811.

Groeneveld, S., and Hartog, J. (2004), 'Overeducation, wages and promotions within the firm', Labour Economics, 11 (6), 701-714.

Groot, W., and Maassen van den Brink, H. (2000), 'Overeducation in the labor market: a meta-analysis', Economics of Education Review, 19 (2), 149-158.

Groot, W., and Maassen van den Brink, H. (2003), 'The dynamics of skill mismatches in the Dutch labour market', in Overeducation in Europe, Büchel F., de Grip A. and Mertens A. (eds.), Edward Elgar: Cheltenham, 49-64.

Hall, R. (1974), 'The process of inflation in the labor market', Brooking Papers on Economic Activity, 2, 343-393.

Hartog, J. (2000), 'Overeducation and earnings: where are we, where should we go?', Economics of Education Review, 19 (2), 131-147.

Livingstone, D. (1998), The Education-Jobs Gap: Underemployment or Economic Democracy, Oxford: Westview Press, 341p.

McGuinness, S. (2003), 'University quality and labour market outcomes’, Applied Economics, 35, 19431955.

McGuinness, S. (2006), 'Overeducation in the labour market’, Journal of Economic Surveys, 20 (3), 387418.

McKelvey, R., and Zavoina, W. (1975), 'A statistical model for the analysis of ordinal level dependent 
variables’, Journal of Mathematical Sociology, 4 (1), 103-120.

OECD (2004), Employment Outlook, Paris: OECD.

OECD (2006), Economic Outlook, Paris: OECD.

OECD (2008a), Employment Outlook, Paris: OECD.

OECD (2008b), Main Science and Technology Indicators, Paris: OECD.

Okun, A. (1981), Prices and Quantities: A Macroeconomic Analysis, Brookings Institution, Washington D.C.

Rabe-Hesketh, S., and Skrondal, A. (2008), Multilevel and Longitudinal Modelling Using Stata, Stata Press: Texas, 562p.

Rabe-Hesketh, S., Skrondal, A., and Pickels, A. (2005), 'Maximum likelihood estimation of limited and discrete dependent variable models with nested random effects', Journal of Econometrics, 128, 301-323.

Reder, M. (1955), 'The theory of occupational wage differentials', American Economic Review, 45, 833852.

Renes, G. and Ridder, G. (1995), ‘Are women overqualified?’, Labour Economics, 2 (1), 3-18.

ROA (2007), 'Schoolverlaters tussen onderwijs en arbeidsmarkt 2006', ROA Report, 2007/3, 116p.

Robst, J. (1995a), 'Career Mobility, job match and overeducation', Eastern Economic Journal, 21 (4), 539-550.

Robst, J. (1995b), ‘College Quality and Overeducation’, Economics of Education Review, 14 (3), 221228.

Rubb, S. (2003), ‘Overeducation: a short or long run phenomenon for individuals?', Economics of Education Review, 22, 389-394.

Scherer, S. (2004), 'Stepping-stones or traps? The consequences of labour market entry positions on future careers in West Germany, Great Britain and Italy’, Work, Employment and Society, 18 (2), 369-394.

Sicherman, N. (1991), 'Overeducation in the Labor Market', Journal of Labor Economics, 9 (2), 101-122.

Sicherman, N., and Galor, O. (1990), 'A theory of career mobility’, Journal of Political Economy, 98 (1), 169-192.

Sloane, P. (2003), 'Much ado about nothing?', in Overeducation in Europe, ed. by F. Büchel, A. de Grip and A. Mertens, Cheltenham: Edward Elgar, 11-45.

Sloane, P., Battu, H., and Seaman, P. (1999), 'Overeducation, undereducation and the British labour market', Applied Economics, 31, 1437-1453.

Snijders, T., and Bosker, R. (1999), Multilevel Analysis, London: Saga Publications, 266p.

Snower, D. (1995), 'The low-skill, bad-job trap', in Acquiring Skills, A. Booth and D. Snower (eds.), CEPR, Cambridge University Press, 109-124.

Spence, M. (1973), 'Job Market Signalling’, Quarterly Journal of Economics, 87 (3), 355-374.

Thurow, L. (1975), Generating Inequality: Mechanisms of distribution in the U.S. economy, New York: Basic Books. 
Van der Velden, R., and Wolbers, M. (2003) 'The integration of young people into the labour market: the role of training systems and labour market regulation', in Transitions from Education to Work in Europe, edited by M. Gangl and W. Müller, Oxford: Oxford University Press.

Veall, M., and Zimmermann, K. (1996), 'Pseudo- $\mathrm{R}^{2}$ measures for some common limited dependent variable models', Journal of Economic Surveys, 10 (3), 241-502.

Verhaest, D., and Omey, E. (2003), 'Overeducation in the transition from school to work: the case of Flanders', The Netherlands' Journal of Social Sciences, 39 (3), 202-226.

Verhaest, D., and Omey, E. (2009), 'Objective over-education and worker well-being: a shadow price approach', Journal of Economic Psychology, 30 (3), 469-481.

Verhaest, D., and Omey, E. (2010), 'The determinants of overeducation: different measures, different outcomes?', International Journal of Manpower, forthcoming.

Verhaest, D., and Schatteman, T. (2010), 'Overeducation in the early career: an analysis using sequence techniques', HUB Research Papers in Economics and Management. 
Appendix A: Construction of the sample

\begin{tabular}{|l|c|c|}
\hline & First job & Current job \\
\hline All respondents (Sweden and Estonia excluded) & 38269 & 38269 \\
Random selection of maximally 2000 cases/country & 24735 & 13746 \\
Never enrolled in other tertiary education program & 13746 & - \\
Employed 6 months after graduation & 11153 & 12524 \\
Employed at time of the survey & - & 11184 \\
Observations with missing values excluded & 9505 & \\
\hline
\end{tabular}




\section{Notes}

${ }^{1}$ A more extended economic literature, dating back to the work of Freeman (1976), focuses on general trends in returns to education. We focus on those studies that conceptualize overeducation as a situation in which individuals have an educational level that exceeds the required level for the job (cf. Hartog, 2000; Green et al., 2002).

${ }^{2}$ For an overview of the construction of these final samples, see Appendix A.

${ }^{3}$ We distinguish a maximum of eight fields of study within each country: (1) education, (2) humanities and arts, (3) social sciences, business and law, (4) science, mathematics and computing, (5) engineering, manufacturing and construction, (6) agriculture and veterinary, (7) health and welfare, and (8) services. For Japan and Switzerland, no observations on subject (8) are available. Those who followed a general program (2 individuals) are excluded.

${ }^{4}$ To evaluate and maximize the likelihood, we make use of adaptive quadrature. As shown by RabeHesketh et al. (2005), adaptive quadrature performs much better than Gauss-Hermite quadrature.

5 As Veall and Zimmermann (1996) showed on the basis of simulations, these scores are close approximations of OLS-R² scores for the underlying latent dependent variables.

${ }^{6}$ Missing values are imputed by their expected values on the basis of OLS regression.

${ }^{7}$ The unemployment gap is measured in relative terms, i.e. the deviation of the unemployment rate from its natural rate divided by the unemployment rate.

${ }^{8}$ Due to missing information, Norwegian R\&D expenditures are for the year 2001.

ix These outcomes can be explained by the negative correlation in our sample $(-0.260)$ between the output gap in the year 2000 and the output gap in the year 2005.

${ }^{10}$ We also executed estimates on the basis of the unemployment rate and unemployment gap in 2005. The coefficient of the unemployment rate in 2005 was never statistically significant. The results for the unemployment gap in 2005 were similar to those for the output gap in 2005: an unexpected statistically significant positive impact if no other country-level variables are controlled for and an statistically insignificant effect once we also control for the output gap in 2000. These results are available upon request. 